EXTENDED REPORT

\title{
Depletion of synovial macrophages in rheumatoid arthritis by an anti-FcrRl-calicheamicin immunoconjugate
}

\author{
J A G van Roon, J W J Bïlsma, J G J van de Winkel, F P J G Lafeber
}

Ann Rheum Dis 2005;64:865-870. doi: 10.1136/ard.2004.028845

See end of article for authors' affiliations .....................

Correspondence to: Dr J A G van Roon, Department of Rheumatology and Clinical Immunology, University Medical Centre Utrecht, F02.127, Utrecht, PO Box $85500,3508 \mathrm{GA}$, The Netherlands; J.vanRoon@ azu.nl

Accepted 9 October 2004 Published Online First 11 November 2004

\begin{abstract}
Background: Monocytes/macrophages have an important and versatile role in joint inflammation and destruction in rheumatoid arthritis (RA).

Objective: To determine the efficiency of monocyte/macrophage elimination by a new drug conjugated antibody (CD64-calicheamicin (CD64-CaMi)) directed to the high affinity receptor for lgG (Fcy RI). Methods: Mononuclear cells from peripheral blood and synovial fluid of patients with RA were cultured in the presence of CD64-CaMi. Cell death of monocytes/macrophages was measured by analysis of phenotypic changes (light scatter patterns, CD14 expression, and Fc $\gamma \mathrm{RI}$ expression) and nuclear DNA fragmentation. The selectivity of CD64-CaMi was checked by using Fc $\gamma$ RI deficient and Fc $\gamma \mathrm{RI}$ transfected cell lines. In addition, the indirect effect of CD64-CaMi-induced macrophage cell death on arthritogenic T(h1) cell activity was determined.

Results: Inflammatory macrophages from RA synovial fluid, expressing increased Fc $\gamma$ RI levels, were efficiently killed by CD64-CaMi through induction of DNA fragmentation. CD64-CaMi-induced cell death of monocytes/macrophages from peripheral blood of patients with RA proved less efficient. Induction of synovial macrophage death by CD64-CaMi was accompanied by efficient inhibition of proinflammatory $\mathrm{T}(\mathrm{h} 1)$ cytokine production.

Conclusion: Together, the presented data suggest that elimination of macrophages through a new Fc $\gamma \mathrm{RI}$ directed CD64-CaMi is feasible. Because monocytes from peripheral blood are also eliminated by this immunoconjugate, additional experimental studies should validate its potential for local (intra-articular) application in the treatment of RA.
\end{abstract}

$P$ atients with rheumatoid arthritis (RA) are characterised by chronic inflammation and destruction of their joints. ${ }^{1}$ Macrophages in the inflamed joints of patients with RA are multitalented cells. It has been suggested that they contribute to joint inflammation by inducing a multitude of biological responses, including the secretion of a wide range of proinflammatory and tissue destructive mediators, and presentation of antigen, resulting in $\mathrm{T}$ cell and (indirectly) B cell activation. ${ }^{23} \mathrm{~A}$ number of approaches to counter macrophage activity have resulted in substantial improvements in the treatment of RA and have increased our understanding of the mechanisms that contribute to joint inflammation. ${ }^{45}$ However, a considerable number of patients with RA do not benefit from these treatments and the effects are transient. It has been recognised that blockade of one or some of the multitude of macrophage effector functions may not be sufficient to control the inflammatory response in RA. ${ }^{6-8}$ Recently, we put forward a new concept to completely block macrophage function by causing selective macrophage elimination exploiting the high affinity receptor for IgG, FC $\gamma$ RI (CD64). ${ }^{910}$

Monocytes and macrophages from patients with RA and healthy controls constitutively express substantial levels of Fc $\gamma$ RI. ${ }^{11-13}$ Antibodies binding to Fc $\gamma$ RI, not only through their Fc tail but also through experimentally generated antibodies that selectively bind to distinct parts of Fc $\gamma \mathrm{RI},{ }^{14}$ are endocytosed very efficiently. ${ }^{15}$ This characteristic of Fc $\gamma$ RI was exploited previously to eliminate macrophages with enhanced Fc $\gamma$ RI expression by using an anti-Fc $\gamma$ RI (CD64) antibody to which the plant ricin toxin A (RTA) was chemically linked (CD64-RTA). Importantly, activated macrophages from RA joints were selectively killed compared with peripheral blood monocytes, ${ }^{10}$ which was related to increased Fc $\gamma$ RI levels on synovial macrophages compared with peripheral blood monocytes. This suggested that in RA Fc $\gamma$ RI might represent a target for other CD64 conjugated drugs to induce a specific elimination of inflammatory macrophages.

To improve the potency of CD64 immunoconjugates we considered another potent drug to target Fc $\gamma$ RI. Members of the enediyne family of antibiotics are among the most toxic compounds described to date ${ }^{16}$ Calicheamicin (CaMi) is a highly potent drug of this family that binds to DNA in a sequence-specific way, thereby causing breaks in double stranded DNA, which represents an initial step leading to cell death. ${ }^{17}$

\section{PATIENTS AND METHODS \\ Patients}

Peripheral blood (PB) and synovial fluid (SF) samples from 12 patients with active RA visiting our outpatient clinic were used. All patients fulfilled the 1987 revised American College for Rheumatology criteria for RA. ${ }^{18}$ Nine patients were rheumatoid factor positive. Patients ranged in age from 46 to 80 years (mean (SD) 61 (11) years), eight patients were treated with methotrexate, three took sulfasalazine, and three received prednisone. Disease duration in the patients ranged from 2 to 42 years (mean (SD) 18 (7) years).

Abbreviations: CaMi, calicheamicin; FSC, forward scatter; IFN $\gamma$, interferon $\gamma ; M C$, mononuclear cells; MFI, mean fluorescence intensity; $\mathrm{PB}$, peripheral blood; $\mathrm{PBS}$, phosphate buffered saline; $\mathrm{PI}$, propidium iodide; RA, rheumatoid arthritis; RTA, ricin toxin A; SSC, side scatter; $\mathrm{SF}$, synovial fluid; $\mathrm{TNF} \alpha$, tumour necrosis factor $\alpha$ 


\section{Cell cultures and reagents}

PB and SF were diluted 1:1 with RPMI 1640 medium (Gibco, $\mathrm{NY}$, USA) containing $2 \mathrm{mM}$ glutamine, $100 \mathrm{U} / \mathrm{ml}$ penicillin, and $\quad 100 \mu \mathrm{g} / \mathrm{ml}$ streptomycin sulphate (RPMI+). Subsequently, mononuclear cells (MC) were isolated by density centrifugation using Ficoll-Paque (Pharmacia, Uppsala, Sweden). The viability of cells, checked by trypan blue exclusion, always exceeded $95 \%$. Isolated PBMC or SFMC $\left(5 \times 10^{6}\right.$ cells $\left./ \mathrm{ml}\right)$ were cultured in RPMI+ supplemented with $10 \%$ pooled human male AB serum (Red Cross blood transfusion centre, Utrecht, The Netherlands) in $200 \mu \mathrm{l}$ round bottomed, 96 well plates under standardised conditions at $37^{\circ} \mathrm{C}$. Culture periods and concentrations of additions such as immunoconjugate are indicated where relevant.

\section{Immunoconjugate}

The immunoconjugate CD64-calicheamicin (CD64-CaMi) was constructed exactly as described for the calicheamicin conjugated CD33 antibody ${ }^{19}$ and was kindly provided by Wyeth Research (Pearl River, NJ). The hydrolysable chemical conjugate allows the CaMi to be released intracellularly from the CD64 monoclonal antibody (H22, Medarex, Annandale, $\mathrm{NJ}, \mathrm{ref}^{20}$ ) through a reducible linker. To make a comparison with other CD64 (H22) conjugated antibodies possible, CD64-CaMi concentrations were calculated from the concentrations of antibody used. The conjugated antibody molecules that were produced contained four CaMi molecules per CD64 (H22) molecule.

\section{Fc $\gamma$ RI expression}

To analyse Fc $\gamma$ RI expression on monocytes and macrophages, SFMC $\left(5 \times 10^{5}\right.$ cells $)$ were double stained with FITC labelled anti-Fc $\gamma$ RI monoclonal antibody (clone 32.2, Medarex) and phycoerythrin labelled CD14 (clone Tuk4, DAKO, Glostrup, Denmark) at $4^{\circ} \mathrm{C}$ for 15 minutes. The Fc $\gamma$ RI detection antibody (clone 32.2) recognises an FcyRI epitope, distinct from the epitope recognised by the CaMi coupled antibody H22 (CD64-CaMi) and is not hindered by binding of CD64CaMi. ${ }^{21}$ After staining, cells were resuspended in phosphate buffered saline (PBS) containing $0.5 \%$ bovine serum albumin and $0.1 \%$ azide and directly analysed by flow cytometry (FACScan, BD) using WinMDI software (BD).

\section{Determination of cell death by light scatter changes and CD 14 expression}

Light scatter changes (forward scatter (FSC) and side scatter (SSC)), detected by FACS analyses (FACScan, BD), are characteristic of cell death. Upon apoptosis induction these light scatter changes most sensitively measure cell death and strongly correlate with trypan blue staining, DNA strand breaks, and Annexin V binding. ${ }^{22}{ }^{23}$ Because loss of CD14 expression was recently shown to be an early effector mechanism by which cell death of monocytes is mediated (for example, induced by interleukin 4 or Fas cross linking), ${ }^{22}$ CDI4 expression levels were also studied as a measure of cell death.

\section{Apoptosis}

To assess macrophage apoptosis, nuclear DNA fragmentation was determined using propidium iodide (PI) staining as described previously. ${ }^{25}$ Briefly, after culture MC were fixed by adding $500 \mu \mathrm{l}$ of cold $70 \%$ ethanol for at least 2 hours at $-20^{\circ} \mathrm{C}$. The cells were then washed with PBS and incubated for 20 minutes at $37^{\circ} \mathrm{C}$ with buffer comprising $0.05 \mathrm{M}$ $\mathrm{Na}_{2} \mathrm{HPO}_{4}, 0.0025 \mathrm{M}$ citric acid, and $0.1 \%$ Triton X-100 to extract small intracellular DNA fragments. During the same period macrophages were stained by FITC labelled CD68 (clone EBM11, DAKO, Glostrup, Denmark). CD68 was used because apoptotic monocytes/macrophages were shown to

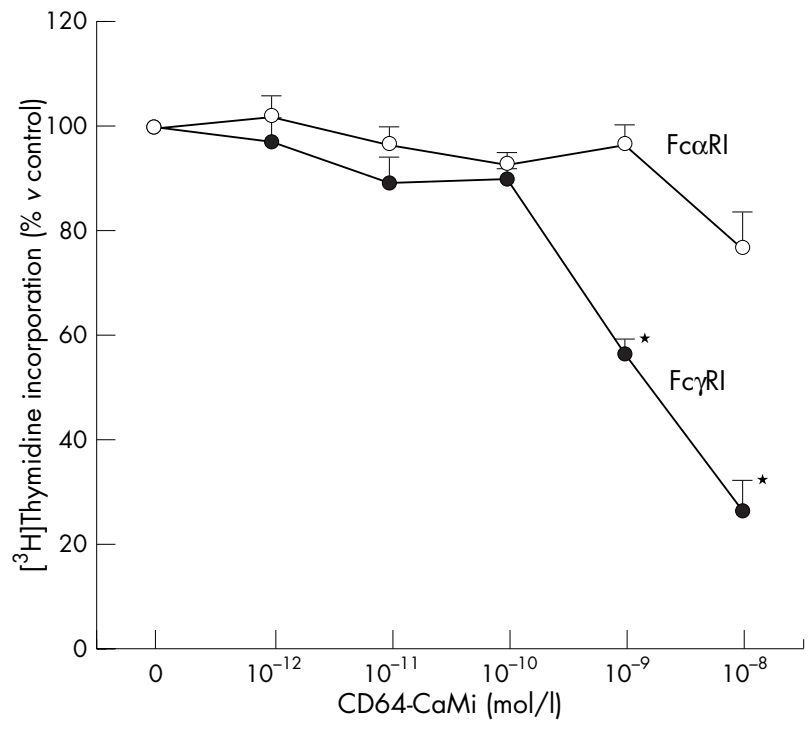

Figure $1 \mathrm{CD} 64-\mathrm{CaMi}$ induces Fc $\gamma \mathrm{RI}$ dependent cell death of $\mathrm{F} \gamma \mathrm{RI}$ transfected, but not FcaRl transfected, IIA 1.6 cells. Proliferation of IIA1.6 cells $\left(2 \times 10^{5} / \mathrm{ml}\right)$ was measured by $\left[{ }^{3} \mathrm{H}\right]$ thymidine incorporation (proliferation) affer 3 days of culture $(n=3)$. The effects of CD64-CaMi were expressed as percentages of control cultures in the absence of immunoconjugate. *Significant difference of $p<0.05$.

lose CD14 expression. CD68 proved to be an intracellular marker with a persistent expression and served to identify apoptotic (and intact) macrophages. After this period, PI (20 $\mu \mathrm{g} / \mathrm{ml}$; Sigma, St Louis, MO) was added to stain the (remaining, subdiploid) nuclear DNA. Fluorescence was subsequently measured by flow cytometry.

\section{Proliferation assays}

To study the efficacy and Fc $\gamma$ RI mediated selectivity of CD64CaMi the inhibition of IIAl.6 cell proliferation was assessed. These cells lack Fc $\gamma \mathrm{R}$ expression and are derived from the murine A20 B cell lymphoma and have been shown to belong to a distinct subset of $\mathrm{CD}^{+} \mathrm{B}$ cell/macrophage cells. ${ }^{26}$ IIAl.6 cells transfected with the FCR $\gamma$-chain cDNA were additionally transfected with either Fc $\gamma$ RI cDNA, or (as a control) Fc $\alpha$ RI cDNA. ${ }^{26} 27$ Transfected IIAl.6 cells $\left(2 \times 10^{5}\right.$ cells $\left./ \mathrm{ml}\right)$ were cultured for 3 days in 96 well, round bottomed plates in RPMI supplemented with $10 \%$ fetal bovine serum, $50 \mu \mathrm{g} / \mathrm{ml}$ gentamicin, $2 \mathrm{mM}$ L-glutamine, $1 \mathrm{mM}$ sodium pyruvate, and $5 \mu \mathrm{M}$ methotrexate. Cells were cultured in the presence or absence of different concentrations of CD64-CaMi $\left(10^{-12}\right.$ $\left.10^{-8} \mathrm{~mol} / \mathrm{l}\right)$. Proliferation was measured by incorporation of methyl $\left[{ }^{3} \mathrm{H}\right]$ thymidine (NEN, Boston, MA) during the last 18 hours of culture.

\section{Cytokine measurements}

To assess the effect of CD64-CaMi-induced macrophage death on Thl cytokine production, SFMC $\left(1 \times 10^{6}\right.$ cells $\left./ \mathrm{ml}\right)$ were cultured in 24 well, flat bottomed plates for 3 days in the presence or absence of CD64-CaMi. To detect modulation of Thl cell activity, which may be due to indirect $\mathrm{T}$ cell death or loss of $\mathrm{T}$ cell activity, $\mathrm{T}$ cell cytokine production after this culture period was assessed upon specific T cell stimulation by soluble CD3/CD28 monoclonal antibodies ( $1 \mu \mathrm{g} / \mathrm{ml}$, CLBT3/4E and CLB-CD28, CLB Reagentia, Amsterdam, The Netherlands) for 24 hours. ${ }^{28}$ Previously we have shown that cytokine production (interferon $\gamma$ (IFN $\gamma$ ), tumour necrosis factor $\alpha(\mathrm{TNF} \alpha))$ of MC upon CD3/CD28 stimulation is for more than $90 \% \mathrm{~T}$ cell derived ${ }^{29}$ and does not require cross linking by Fc $\gamma$ receptors on antigen presenting cells. ${ }^{29}{ }^{30}$ After 

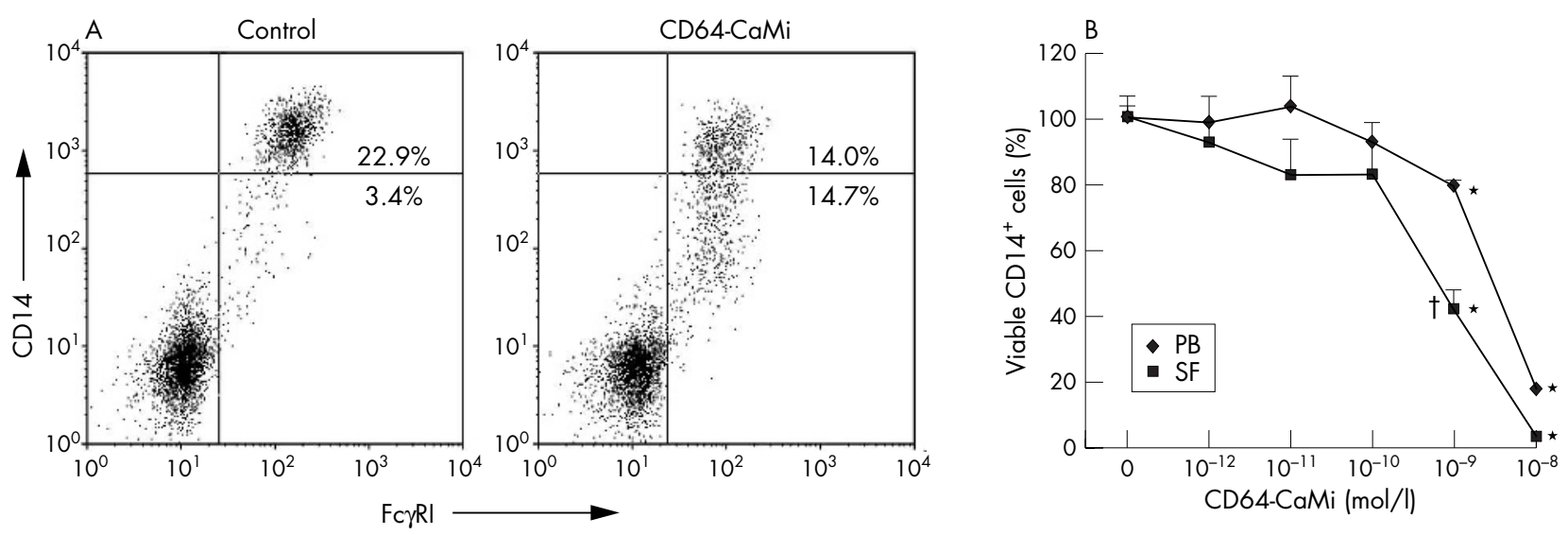

Figure 2 Flow cytometric analysis of the effect of CD64-CaMi on PB monocytes and SF macrophages from patients with RA. (A) Representative Fc $\gamma \mathrm{RI} /$ CD14 staining of MC from PB and SF cultured for 24 hours with or without CD64-CaMi. CD64-CaMi-induced death of monocytic cells was associated with a reduction in $\mathrm{CDI} 4^{+}$monocytic cells from $22.9 \%$ to $14.0 \%$ (almost $40 \%$ reduction). (B) Average of CD64-CaMi-induced monocyte/macrophage cell death from PB and SF (both $n=6$ ) are expressed as a decrease in viable cells compared with controls, measured as a reduction in CDI 4 expression after 24 hours of culture. *Significant differences of CD64-CaMi-induced cell death compared with control cultures ( $p<0.05)$. At a CD64-CaMi concentration of $10^{-9} \mathrm{~mol} / \mathrm{l}$, cell death of macrophages from SF, measured by reduction in CD14+ cells (mean (SD) 57 (7)\%), was significantly higher than in PB (19 (3)\%; $\uparrow \mathrm{p}<0.05)$.

this $\mathrm{T}$ cell stimulation, media were harvested and freed of cellular material by centrifugation $(5$ minutes, $900 \mathrm{~g}$ ), frozen in liquid nitrogen, and stored at $-20^{\circ} \mathrm{C}$. IFN $\gamma$ and $\mathrm{TNF} \alpha$ levels in the culture supernatants were determined by enzyme linked immunosorbent assay (ELISA) according to the manufacturer's instructions (Biosource Europe, Nivelles, Belgium).

\section{Statistical analyses}

Wilcoxon and Mann-Whitney U tests were used for nonpaired and paired observations, respectively. Spearman statistical tests were used for correlation analyses. Data were considered significant at $\mathrm{p}<0.05$.

\section{RESULTS}

Induction of FcyRI dependent cell death by CD64-CaMi To test whether CD64-CaMi can trigger selective Fc $\gamma$ RI dependent cell death, the effect of the immunoconjugate was evaluated on the proliferation of the IIAl.6 B cell/ macrophage lymphoma cell line, which lacks Fc $\gamma$ Rs. ${ }^{26}$ IIAl.6 cells, stably transfected with Fc $\gamma$ RI (and the Fc $\gamma$ R $\gamma$-chain), were efficiently killed by CD64-CaMi as observed by a strong reduction in proliferation, at concentrations of $10^{-9}$ and $10^{-8} \mathrm{~mol} / \mathrm{l}$ (fig 1). IIAl.6 cells expressing a transfected control Fc receptor, Fc $\alpha$ RI (and the Fc $\gamma \mathrm{R} \gamma$-chain) were not significantly affected by CD64-CaMi, indicating that CD64CaMi selectively induces Fc $\gamma$ RI dependent killing.
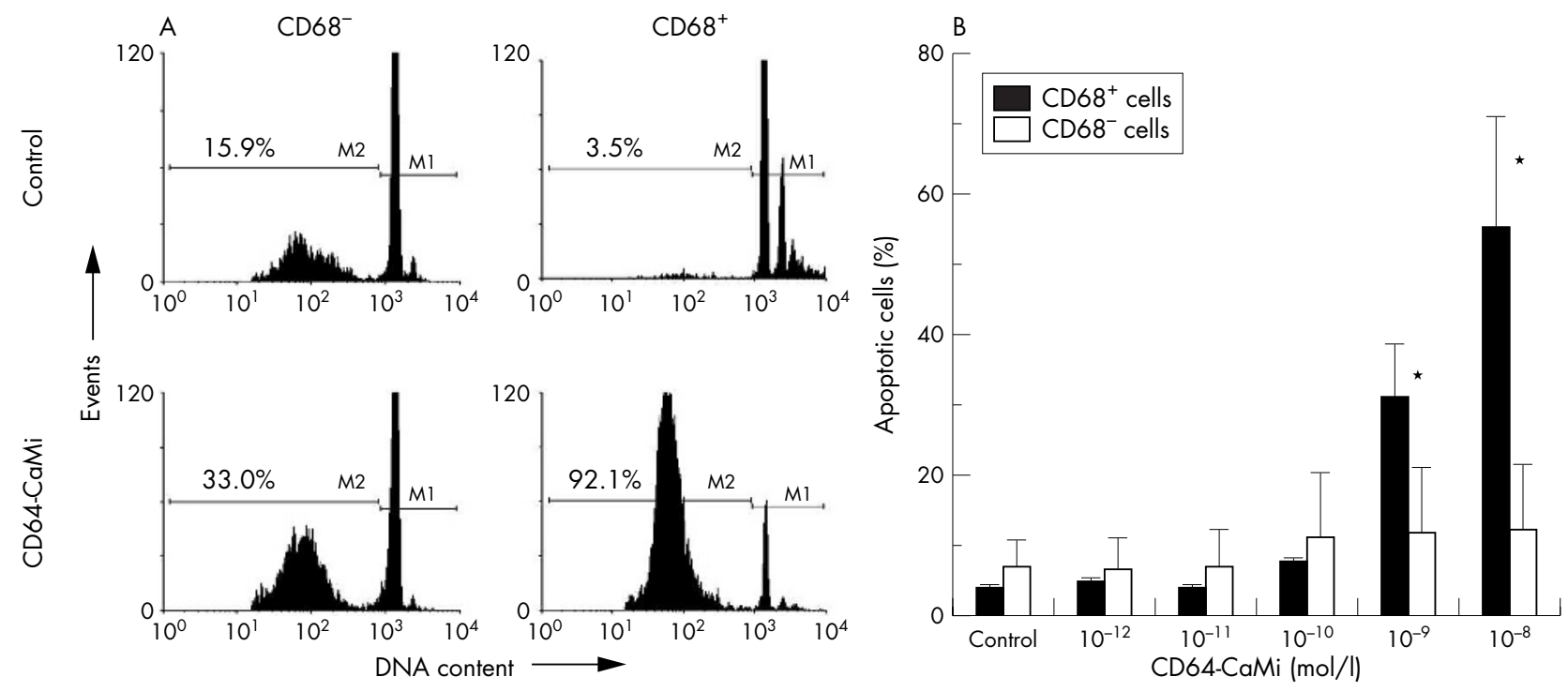

Figure 3 Induction of nuclear DNA fragmentation of CD68 ${ }^{+}$cells by CD64-CaMi. DNA content of CD68 $8^{-}$lymphocytic and $C D 68^{+}$monocytic cells was stained with PI and measured by flow cytometry (FACS). (A) Representative analysis showing that incubation of SFMC with CD64-CaMi $\left(10^{-8} \mathrm{~mol} / \mathrm{l}\right.$ for 24 hours) results in a strong increase in apoptotic $\mathrm{CD} 68^{+}$cells with reduced nuclear DNA content owing to DNA fragmentation (from $3.5 \%$ to $92.1 \%$ of $C D 68^{+}$cells). (B) On average ( $n=3,10^{-8} \mathrm{~mol} / \mathrm{I}$ for 24 hours), a mean (SD) change from 4.2 (0.2)\% apoptotic macrophages in control culture to $57.5(18.5) \%$ upon culture with CD64-CaMi $(p<0.05)$ was seen. Apoptotic cell death of CD68 lymphocytic cells was not significantly changed (8.2 (4.0)\% to $13.1(8.9) \%)$. *Significant cell death of $\mathrm{CD}^{+} 8^{+}$cells $(\mathrm{p}<0.05)$. 


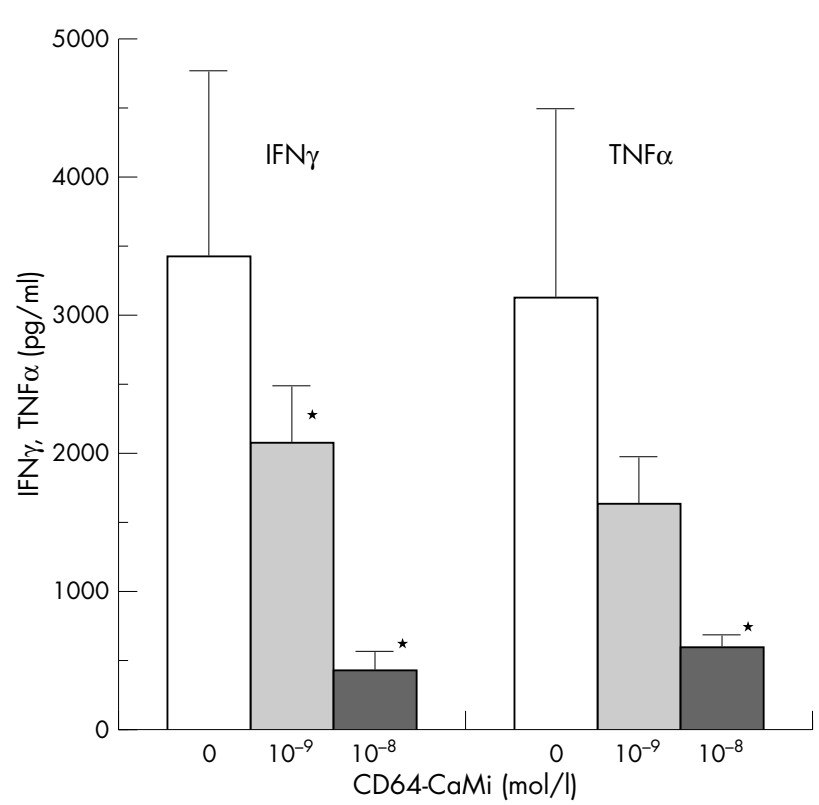

Figure 4 CD64-CaMi-induced macrophage apoptosis in time prevents CD3/CD28-induced T cell cytokine secretion $(n=3)$. SFMC were cultured with CD64-CaMi at a concentration of $10^{-8} \mathrm{~mol} / \mathrm{l}$ and $10^{-9} \mathrm{~mol} / \mathrm{l}$ or without CD64-CaMi for 3 days. After this, T cells were costimulated by CD3/CD28 for 24 hours, and IFN $\gamma$ and TNF $\alpha$ levels were measured. *Significant inhibitions of T cell activity upon (pre-) treatment with CD64-CaMi compared with control cultures $(p<0.05)$.

\section{CD64-CaMi immunoconjugate induces death of monocytes/macrophages from patients with RA}

As shown in previous studies, ${ }^{10}{ }^{12}{ }^{13}$ Fc $\gamma$ RI was expressed at substantial levels on monocytes/macrophages from both PB and SF from patients with RA (fig 2A). The Fc $\gamma$ RI expression level was significantly higher on SF than on PB monocytes/ macrophages $(\mathrm{p}<0.05$, data not shown $)$.

On the basis of the FSC-SSC, characteristics of subpopulations of MC can be distinguished that consist mainly of lymphocytes or monocytes/macrophages. Based on decreases in FSC and SSC, characteristic of cell death, incubation with CD64-CaMi for 24 hours resulted in cell death of monocytes/ macrophages (data not shown). Macrophage death assessed by light scatter changes strongly correlated with more specific markers of macrophage death, ${ }^{10}$ such as CDI4 expression (fig 2) and nuclear DNA fragmentation of $\mathrm{CD}^{+} 8^{+}$cells (fig 3).

Down regulation of CDl4 expression on monocytes/ macrophages by several reagents represents an early event in the apoptotic cascade of these cells and correlates with increased DNA fragmentation. ${ }^{1022-24}{ }^{31}$ CD64-CaMi-induced monocyte/macrophage cell death, measured by CD14 reduction and consequently a reduced number of $\mathrm{CD}^{+} 4^{+}$cells (representative analysis is shown in fig 2A), was found to be significant at concentrations of $10^{-9}$ and $10^{-8} \mathrm{~mol} / \mathrm{l}$ (fig $2 \mathrm{~B}$ ). For CD64-CaMiAt a concentration of $10^{-9} \mathrm{~mol} / \mathrm{l}$ the decrease in viable SF CD $14^{+}$cells was significantly higher than that of PB CD14+ cells $(\mathrm{p}<0.05)$.

The reduction of $\mathrm{SF} \mathrm{CDI}^{+}$cells by CD64-CaMi was associated with Fc $\gamma$ RI down regulation. The average of the mean (SEM) fluorescence intensity (MFI) of Fc $\gamma$ RI at control 174 (31) was significantly $(\mathrm{p}<0.05)$ reduced to $104(19)$ at $10^{-9} \mathrm{~mol} / \mathrm{l}$ (at $10^{-8} \mathrm{~mol} / \mathrm{l}$ the cell number to analyse was too low to permit a reliable calculation of Fc $\gamma$ RI expression levels). The effects on Fc $\gamma$ RI expression levels of PB CD $14^{+}$ cells (mean (SEM) MFI at control 101 (15) to 48 (5) at $10^{-9} \mathrm{~mol} / \mathrm{l}, \mathrm{p}<0.05$ ) were of the same order. Although Fc $\gamma$ RI expression levels on SF macrophages were higher than on monocytes and CD64-CaMi-induced killing was more efficient for SF macrophages than for PB monocytes, we could not detect a significant correlation between these two measures.

\section{Monocyte/macrophage death induced by CD64-CaMi is mediated by DNA fragmentation}

Nuclear DNA fragmentation represents a hallmark of the apoptotic process and was measured by PI staining of nuclear DNA upon extraction of intracellular fragmented DNA. ${ }^{25}$ Figure 3 shows a representative experiment of reduction in DNA content of $\mathrm{CD}^{+} 8^{+}$cells with and without immunoconjugate treatment. Incubation for 24 hours with CD64-CaMi resulted in a strong increase in dead $\mathrm{CD} 68^{+}$cells with reduced levels of nuclear DNA (fig 3B; on average from $4.2(0.2)$ to $57.5(18.5) \%$ at $\left.10^{-8} \mathrm{~mol} / \mathrm{l}, \mathrm{p}<0.05\right)$. In contrast with these effects, no significant cell death of $\mathrm{CD}^{-} 8^{-}$lymphocytes was found (from $8.2(4.0)$ to $13.0(8.9)$ at $10^{-8} \mathrm{~mol} / \mathrm{l}$ ). In line with these results, only minimal effects were observed when cell death of lymphocytes was measured by reduction in cell size (data not shown), which is characteristic of cell death ${ }^{102}$ and detected by light scatter changes using flow cytometry.

\section{Macrophage death is followed by abrogation of lymphocyte activation}

Macrophages, in particular, play a crucial part in the persistent $\mathrm{T}$ cell activity in RA by cell-cell contact and the production of soluble mediators. ${ }^{3}$ Therefore, it was tested whether CD64-CaMi-induced macrophage death could prevent Thl cell activity. After 3 days of culture in the absence of the immunoconjugate, $\mathrm{T}$ cells, upon restimulation with $\mathrm{CD} 3 /$ CD28, produced considerable amounts of IFN $\gamma$ and TNF $\alpha$. Previously we have shown that this production is for more than $90 \% \mathrm{~T}$ cell derived. ${ }^{29} \mathrm{~T}$ cell cytokine production was strongly prevented when macrophages had been deleted by CD64-CaMi (fig 4). Interleukin 4 production at all times was below the detection limit (data not shown).

\section{DISCUSSION}

This study shows an efficient and selective depletion of monocytes/macrophages by using an Fc $\gamma$ RI directed immunoconjugate (CD64-CaMi). Cell death of activated macrophages was associated with DNA fragmentation, and was followed in time by a reduction in Thl cell activity.

Induction of cell death by CD64-CaMi seems to be more potent than CD64-RTA. ${ }^{10}$ At an optimal concentration $\left(10^{-8} \mathrm{~mol} / \mathrm{l}\right)$ the induction of cell death (measured by CDI4 reduction) by CD64-CaMi for both $\mathrm{PB}$ monocytes and SF macrophages is stronger ( $83 \%$ and $97 \%$, respectively) than cell death induced by CD64-RTA, which we have previously described ( $18 \%$ and $54 \%$ cell death, respectively). ${ }^{10}$ The finding that both synovial macrophages and monocytes from the circulation were efficiently killed by CD64-CaMi differs from the results with CD64-RTA. This latter immunoconjugate was shown to induce death of synovial macrophages more efficiently than monocytes at a similar concentration of CD64 antibody as used in the present study. ${ }^{10}$ This difference in killing of monocytes may be due to different mechanisms of action between CaMi and RTA. Whereas RTA inhibits protein synthesis and induces caspase activity that finally leads to DNA damage and fragmentation, ${ }^{32}$ CaMi translocates to the nucleus, where it binds DNA and directly causes DNA strand breaks. ${ }^{17}$ RA synovial macrophages differ greatly from monocytes in their activation status and protein synthesis. This could contribute to the different killing efficiencies in macrophages and monocytes by RTA compared with CaMi. Cell death of monocytic cells induced by CaMi may consequently be less dependent on the activation 
status and Fc $\gamma$ RI expression level. This might explain why CD64-CaMi-induced cell death does not correlate tightly with Fc $\gamma$ RI expression levels, in contrast with CD64-RTA-induced cell death. ${ }^{10}$

Activated $\mathrm{T}$ cells are present in large numbers in RA joints and it is suggested that they contribute strongly to joint inflammation by the activation of macrophages and $B$ cells. $^{33} 34$ Previously it was shown that CD64-RTA-induced cell death of synovial macrophages cocultured with lymphocytes is followed in time by the abrogation of Thl driven, ${ }^{35} 36$ antigen-induced (mycobacterial heat shock protein 60) lymphocyte responses. ${ }^{10}$ The present study supports the assumption that elimination of monocytic cells by a CD64 immunoconjugate can lead to an almost complete prevention of Thl cell responses (IFN $\gamma$ and TNF $\alpha$ production), owing to a decreased costimulatory function of the monocytic cells. In line with these data, $\mathrm{T}$ cell resolution in cutaneous inflammation was seen in mice after local elimination of dermal macrophages by CD64-RTA. ${ }^{9}$ Together these data suggest that CD64 immunoconjugates could lead to resolution of inflammation not only by removing inflammatory monocytic cells but also, indirectly, by preventing lymphocytic responses.

Previously CD64-RTA was shown to selectively eliminate activated synovial macrophages, whereas only a small percentage of circulating monocytic cells were affected. This suggested that such an immunoconjugate might be safe in the systemic treatment of patients with RA. In support of this it was found that systemic administration of CD64-RTA successfully inhibited experimental arthritis in a human Fc $\gamma$ RI transgenic rat model and was well tolerated without significant side effects (manuscript submitted for publication). The present work shows effective killing of monocytic cells from the site of inflammation and from the circulation. Because monocytes also have a role in the defence against pathogens this suggests that systemic administration of CD64-CaMi could lead to an undesired immune compromising state. However, in persistently inflamed joints, local (intra-articular) elimination of both macrophages and monocytes by CD64-CaMi may be desirable. This may not only lead to elimination of persistent inflammatory macrophages but also elimination of recently infiltrated monocytes from PB that could start to contribute to the inflammatory process. The resolution of skin inflammation after elimination of $\mathrm{Fc}_{\mathrm{R}} \mathrm{RI}^{+}$cutaneous inflammatory macrophages upon local administration indicates the efficiency and safety of this approach. ${ }^{937}$ Further studies should disclose the effectiveness and potential risks of CD64-CaMi in arthritis upon intraarticular administration.

This study indicates that Fc $\gamma \mathrm{RI}$ on synovial macrophages is a suitable target for immunoconjugate mediated depletion of these versatile cells that have an important proinflammatory role in RA, as well as other joint diseases. Future studies should, however, validate the potential of Fc $\gamma$ RI directed immunoconjugates as therapeutic agents for treatment of RA.

\section{ACKNOWLEDGEMENT}

This work was financially supported by a grant from the Dutch Technology Foundation (STW).

\section{Authors' affiliations \\ J A G van Roon, J W J Bïlsma, F P J G Lafeber, Department of Rheumatology and Clinical Immunology, University Medical Centre Utrecht, Utrecht, PO Box 85500, 3508 GA, The Netherlands J A G van Roon, J G J van de Winkel, Immunotherapy Laboratory, Department of Immunology, University Medical Centre Utrecht, PO Box} 85500, 3508 GA, The Netherlands

J G J van de Winkel, Genmab, Utrecht, The Netherlands

\section{REFERENCES}

1 Mulherin D, Fitzgerald O, Bresnihan B. Synovial tissue macrophage populations and articular damage in rheumatoid arthritis. Arthritis Rheum 1996;39:115-24.

2 Burmester GR, Stuhlmuller B, Keyszer G, Kinne RW. Mononuclear phagocytes and rheumatoid synovitis. Mastermind or workhorse in arthritis? Arthritis Rheum 1997;40:5-18.

3 Choy EH, Panayi GS. Cytokine pathways and joint inflammation in rheumatoid arthritis. N Engl J Med 2001;344:907-16.

4 Bresnihan B. The safety and efficacy of interleukin-1 receptor antagonist in the treatment of rheumatoid arthritis. Semin Arthritis Rheum 2001;30(suppl 2): 17-20.

5 Elliott MJ, Maini RN, Feldmann M, Kalden JR, Antoni C, Smolen JS, et al. Randomised double-blind comparison of chimeric monoclonal antibody to tumour necrosis factor alpha (cA2) versus placebo in rheumatoid arthritis. Lancet 1994;344:1105-10.

6 Barrera P, Blom A, van Lent PL, van Bloois L, Beijnen JH, van Rooijen N, et al. Synovial macrophage depletion with clodronate-containing liposomes in rheumatoid arthritis. Arthritis Rheum 2000;43:1951-9.

7 Hahn G, Stuhlmuller B, Hain N, Kalden JR, Pfizenmaier K, Burmester GR. Modulation of monocyte activation in patients with rheumatoid arthritis by leukapheresis therapy. J Clin Invest 1993;91:862-70.

8 Hidaka T, Suzuki K, Matsuki Y, Takamizawa-Matsumoto M, Kataharada K, Ishizuka T, et al. Filtration leukocytapheresis therapy in rheumatoid arthritis: a randomized, double-blind, placebo-controlled trial. Arthritis Rheum 1999;42:431-7.

9 Thepen T, van Vuuren AJ, Kiekens RC, Damen CA, Vooijs WC, van de Winkel JG. Resolution of cutaneous inflammation after local elimination of macrophages. Nat Biotechnol 2000;18:48-51.

10 van Roon JA, van Vuuren AJ, Wiingaarden S, Jacobs KM, Bijlsma JW, Lafeber FP, et al. Selective elimination of synovial inflammatory macrophages in rheumatoid arthritis by an Fcgamma receptor I-directed immunotoxin. Arthritis Rheum 2003;48:1229-38.

11 Deo YM, Graziano RF, Repp R, van de Winkel JG. Clinical significance of IgG Fc receptors and Fc gamma R-directed immunotherapies. Immunol Today 1997; 18:127-35.

12 Highton J, Carlisle B, Palmer DG. Changes in the phenotype of monocytes/ macrophages and expression of cytokine mRNA in peripheral blood and synovial fluid of patients with rheumatoid arthritis. Clin Exp Immunol 1995; 102:541-6.

13 Wiingaarden S, van Roon JA, Biilsma JW, van de Winkel JG, Lafeber FP. Fcgamma receptor expression levels on monocytes are elevated in rheumatoid arthritis patients with high erythrocyte sedimentation rate who do not use antirheumatic drugs. Rheumatology (Oxford) 2003;42:681-8.

14 Liu C, Goldstein J, Graziano RF, He J, O'Shea JK, Deo Y, et al. F(c)gammaRItargeted fusion proteins result in efficient presentation by human monocytes of antigenic and antagonist T cell epitopes. J Clin Invest 1996;98:2001-7.

15 Heijnen IA, van Vugt MJ, Fanger NA, Graziano RF, de Wit TP, Hofhuis FM, et al. Antigen targeting to myeloid-specific human Fc gamma RI/CD64 triggers enhanced antibody responses in transgenic mice. J Clin Invest 1996;97:331-8.

16 Trail PA, Bianchi AB. Monoclonal antibody drug conjugates in the treatment of cancer. Curr Opin Immunol 1999;11:584-8.

17 Zein N, Sinha AM, McGahren WJ, Ellestad GA. Calicheamicin gamma 1I: an antitumor antibiotic that cleaves double-stranded DNA site specifically. Science 1988;240:1198-201.

18 Arnett FC, Edworthy SM, Bloch DA, McShane DJ, Fries JF, Cooper NS, et al. The American Rheumatism Association 1987 revised criteria for the classification of rheumatoid arthritis. Arthritis Rheum 1988;31:315-24.

19 Naito K, Takeshita A, Shigeno K, Nakamura S, Fujisawa S, Shinjo K, et al. Calicheamicin-conjugated humanized anti-CD33 monoclonal antibody (gemtuzumab zogamicin, CMA-676) shows cytocidal effect on CD33-positive leukemia cell lines, but is inactive on P-glycoprotein-expressing sublines. Leukemia 2000;14:1436-43.

20 Graziano RF, Tempest PR, White P, Keler T, Deo Y, Ghebremariam H, et al. Construction and characterization of a humanized anti-gamma-lg receptor type I (Fc gamma RI) monoclonal antibody. J Immunol 1995; 155:4996-5002.

21 Guyre PM, Graziano RF, Vance BA, Morganelli PM, Fanger MW. Monoclonal antibodies that bind to distinct epitopes on Fc gamma RI are able to trigger receptor function. $J$ Immunol 1989;143:1650-5.

22 Heidenreich S, Schmidt M, August C, Cullen P, Rademaekers A, Pauels HG Regulation of human monocyte apoptosis by the CD14 molecule. J Immunol 1997; 159:3178-88.

23 Koester SK, Schlossman SF, Zhang C, Decker SJ, Bolton WE. APO2.7 defines a shared apoptotic-necrotic pathway in a breast tumor hypoxia model. Cytometry 1998;33:324-32

24 Perlman H, Pagliari L, Liu H, Koch AE, Haines GK, III, Pope RM. Rheumatoid arthritis synovial macrophages express the Fas-associated death domain-like interleukin-1 beta-converting enzyme-inhibitory protein and are refractory to Fas-mediated apoptosis. Arthritis Rheum $2001 ; 44: 21-30$.

25 Nicoletti I, Migliorati G, Pagliacci MC, Grignani F, Riccardi C. A rapid and simple method for measuring thymocyte apoptosis by propidium iodide staining and flow cytometry. J Immunol Methods 1991;139:271-9.

26 van Vugt MJ, Van den Herik-Oudiik IE, van de Winkel JG. FcgammaRlagamma-chain complexes trigger antibody-dependent cell-mediated cytotoxicity (ADCC) in CD5+B cell/macrophage IIA1.6 cells. Clin Exp Immunol 1998;113:415-22.

27 Reterink TJ, van Zandbergen G, van Egmond M, Klar-Mohamad N, Morton $\mathrm{CH}$, van de Winkel JG, et al. Size-dependent effect of $\lg A$ on the $\lg \mathrm{A}$ Fc receptor (CD89). Eur J Immunol 1997;27:2219-24. 
28 Verhoef CM, van Roon JA, Vianen ME, Glaudemans CA, Lafeber FP Biilsma JW. Lymphocyte stimulation by CD3-CD28 enables detection of low T cell interferon-gamma and interleukin-4 production in rheumatoid arthritis. Scand J Immunol 1999:50:427-32.

29 Verhoef CM, van Roon JA, Vianen ME, Bijlsma JW, Lafeber FP. Interleukin 10 (IL-10), not IL-4 or interferon-gamma production, correlates with progression of joint destruction in rheumatoid arthritis. J Rheumatol 2001;28:1960-6.

30 Hilkens CM, Vermeulen H, van Neerven RJ, Snijdewint FG, Wierenga EA, Kapsenberg ML. Differential modulation of Thelper type 1 (Th1) and T helper type 2 (Th2) cytokine secretion by prostaglandin E2 critically depends on interleukin-2. Eur J Immunol 1995;25:59-63.

31 Heidenreich S. Monocyte CD14: a multifunctional receptor engaged in apoptosis from both sides. J Leukoc Biol 1999;65:737-43.

32 Thrush GR, Lark LR, Clinchy BC, Vitetta ES. Immunotoxins: an update. Annu Rev Immunol 1996;14:49-71.

33 Morita Y, Yamamura M, Kawashima M, Harada S, Tsuji K, Shibuya K, et al Flow cytometric single-cell analysis of cytokine production by CD4+T cells in synovial tissue and peripheral blood from patients with rheumatoid arthritis. Arthritis Rheum 1998;41:1669-76.

34 Yudoh K, Matsuno H, Nakazawa F, Yonezawa T, Kimura T. Reduced expression of the regulatory CD4+T cell subset is related to Th1/Th2 balance and disease severity in rheumatoid arthritis. Arthritis Rheum 2000;43:617-27.

35 van Roon JA, van Roy JL, Duits A, Lafeber FP, Biilsma JW. Proinflammatory cytokine production and cartilage damage due to rheumatoid synovial $\mathrm{T}$ helper- 1 activation is inhibited by interleukin-4. Ann Rheum Dis 1995; $54: 836-40$

36 van Roon JA, van Eden W, van Roy JL, Lafeber FJ, Bijlsma JW Stimulation of suppressive T cell responses by human but not bacterial 60-kD heat-shock protein in synovial fluid of patients with rheumatoid arthritis. J Clin Invest 1997;100: 459-63.

37 McCormick TS, Stevens SR, Kang K. Macrophages and cutaneous inflammation. Nat Biotechnol 2000;18:25-6.

\section{bmjupdates+}

bmiupdates+ is a unique and free alerting service, designed to keep you up to date with the medical literature that is truly important to your practice.

bmjupdates+ will alert you to important new research and will provide you with the best new evidence concerning important advances in health care, tailored to your medical interests and time demands.

\section{Where does the information come from?}

bmjupdates+ applies an expert critical appraisal filter to over 100 top medical journals A panel of over 2000 physicians find the few 'must read' studies for each area of clinical interest

Sign up to receive your tailored email alerts, searching access and more...

www.bmjupdates.com 